REVIEW PAPERS

\title{
IDENTIFICATION, ASSESSMENT AND ORDERING OF CONCEPTS FOR AGRO-ENERGY PLANNING AND POSSIBILITIES OF SPATIAL ANALYSIS
}

Doi:http://dx.doi.org/10.1590/1809-4430-Eng.Agric.v35n6p 1210-1223/2015

\section{WALTER R. CERVI ${ }^{1}$, RUBENS LAMPARELLI $^{2}$, MAURO BERNI $^{3}$, JANSLE ROCHA $^{4}$}

\begin{abstract}
The present study aims to present the main concepts of the sugarcane straw to energy planning. Throughout the study, the subject is contextualized highlighting broader aspects of sustainability, which is considered the main driver towards agro-energy modernization. Concerning sugarcane straw, we first evaluated its availability regarding technical and economic aspects, and then it summarized the straw production chain for energy supply purposes. As a proposal to support agro-energy planning, it is presented some spatial tools that have been barely used in the Brazilian energy planning context so far. Therefore, working on straw to electricity associated with supply chain basis, we developed a conceptual model to spatially assess this bioenergy system. Using the model proposed, it is described the whole supply chain at state level, which accounted the potential of a single mill to explore straw, as well as main costs associated with straw acquisition, investments on the straw recovery routes and electricity transmission. Bearing these concepts in mind, it is fully believed that spatial analysis can bring important information for agro-energy action plans.
\end{abstract}

KEYWORDS: sugarcane, straw, agro-energy planning, geographic information system.

\section{IDENTIFICAÇÃO, AVALIAÇÃO E ORDENAMENTO DE CONCEITOS PARA O PLANEJAMENTO AGROENERGÉTICO E AS POSSIBILIDADES DA ANÁLISE ESPACIAL}

RESUMO: O presente artigo busca apresentar os principais conceitos envolvendo um planejamento energético específico da palha da cana-de-açúcar. Ao longo do trabalho, procurou-se contextualizar o tema por meio de questões de sustentabilidade, considerada um dos principais indutores em direção à modernização da agroenergia. Considerando a palha da cana de açúcar, avaliou-se primeiramente sua disponibilidade envolvendo aspetos técnicos e econômicos, e posteriormente caracterizou-se a cadeia de produção da palha para energia. Como proposta para auxílio ao planejamento agroenergetico, apresentou-se algumas ferramentas espaciais que até então pouco têm sido utilizadas para planejamento energético no Brasil. Deste modo, trabalhando o potencial de palha para eletricidade associado à sua cadeia de produção, desenvolveu-se um modelo conceitual para se avaliar espacialmente esse sistema bioenergético. Utilizando o modelo proposto, foi possível descrever toda a cadeia de produção da palha para energia em um nível estadual, envolvendo o potencial que cada usina pode explorar, bem como os principais custos associados à sua aquisição, investimentos relacionados à rota de recuperação e em linhas de transmissão. Por meio dos conceitos abordados, acredita-se que análise espacial pode trazer importantes informações para planos de ação no âmbito agroenergético.

PALAVRAS-CHAVE: cana-de-açúcar, palha, planejamento energético, sistema de informação geo gráfica.

\footnotetext{
${ }^{1}$ Geógrafo, Mestre, Faculdade de En genharia A grícola/Unicamp - Avenida Cândido Rondon 501, Barão Geraldo/Campinas - SP, Fone: (19) 3521-1113, waltercervi@ gmail.com

${ }^{2}$ Eng $^{\circ}$ A grícola,Doutor, Núcleo Interdisciplinar de Planejamento Energético/Unicamp - Barão Geraldo/Campinas - SP, Fone: (19) 3521-1250, rubens.lamparelli@ gmail.com

${ }^{3}$ Eng $^{\circ}$ Mecânico,Doutor, Núcleo Interdisciplinar de Planejamento Energético/Unicamp - Barão Geraldo/Campinas - SP, Fone: (19) 3521-1268, mberni@unicamp.br

${ }^{4}$ Eng $^{\circ}$ A grícola, Prof. Doutor, Faculdade de En genharia A grícola/Unicamp, Campinas-SP, Fone (19)3521-1010,

jansle.rocha@feagri.unicamp.br

Recebido pelo Conselho Editorial em: 13-3-2014
}

Aprovado pelo Conselho Editorial em: 25-5-2015 


\section{INTRODUCTION}

As a result of many energy crisis that have been established throughout the decades, primarily since the first petroleum crisis in 1973, discussions on global and national levels about energy developments have intensely increased over the past years. The emergence of the sustainability as a premise to generate new types of energy follows these discussions, offering directives, proposing projects of Research and Development (R\&D), formulating concepts and agendas. Considering this conjuncture, the agricultural sector, due to the annual success in different cropping seasons and also due to the incentives that receives from different institutions, must hold a prominent position front of the energy directive framework.

Among the main models of renewable energy generation, the use of biomass is together with hydropower one of the most traditional vectors in Brazil (ANEEL, 2013), initiated in the 1970's by the Ethanol National Program (PróÁlcool). Since then, sugarcane mills have expanded their energy production, essentially in the state of São Paulo, which is the leader of sugarcane and ethanol production in the country (UNICA, 2013). The modernization of the ind ustrial plant in the sugarcane mills is another key factor to the sector succeeds. The development of sugarcane processing technologies led the agroindustry to expand its products, as an example, the energy selfsufficiency in the industrial plant and the commercialization of the surpluses are constantly highlighted (LEAL \& MACEDO, 2004).

Conversely, the sugarcane agricultural management techniques did not follow the modernization of the industrial plants in a synchronized mode. Until recently, the harvest practices in great part of the state, dealt with the outdated process of straw burning during the harvest period (CANASAT, 2013). In this context, environmental discussions have grown and raised awareness about the problems that the burning practice could cause in the society, leading discussions towards a reordering of the territorial drivers responsible for the energy production, and therefore it becomes one of the main challenges for the sugarcane sector. For this reason, the sugarcane economy urgently requires a sustainable production model, aiming the maximization of economical use of its products and byproducts (BUCKERIDGE et al., 2012).

In this perspective, $R \& D$ organizations have been constantly cooperating with the sugarcane sector to formulate studies and providing better initiatives to the bioenergy production chain (FAPESP, 2012). Through research conducted in this sector, the agroindustry is subsidized for better decision-making, social and scientific commitments, as well as fruitful insights to optimize the cost and benefits.

In this aspect, planning techniques corresponds a great part of the studies addressed to the sugarcane sector and have been increasingly used by researchers as they provide subsidies to a strategic territorial management. Thus, geotechnologies are inserted in this scope so as to integrate, manipulate and interpolate information from the main components of the sugarcane to energy production chain. Accordingly, there is a growth in use of satellite data (and airborne) and modern computational platforms for agro-energy planning and management.

For all these reasons, aiming to analyze the conditions of sugarcane to energy production chain and the possibilities of planning under the systematic view of the spatial analysis, we present a discussion regarding the sugarcane to agro-energy planning, emphasizing the state of São Paulo. The study dealt with the reuse of the sugarcane residue left on field - straw - for power generation purposes, and provides a conceptual model to demonstrate the importance spatial analysis to support decision-making for agro-energy planning.

\section{Contextualization of the sugarcane biomass to energy}

The replacement of fossil energy sources in big consumer markets for less pollutant options from renewable sources (e.g. sugarcane biomass) has been caused a great movement of international capitals (AMORIM, 2007). Brazil in this regard, due to favorable agricultural conditions and 40 years of technological experience, has drawn the attention of international 
investments, which contributed to increase the production in order to supply a growing domestic market and also international demands (FREITAS \& KANEKO, 2011; LAMERS et al., 2011).

Energy security, oil prices and sustainability issues are examples that endorse the global investments in renewable energy. Indeed, the sustainability aspect is one of the main subjects and has driven the agricultural expansion for energy purposes (IPCC, 2014). In this sense, it is important to comprehend not only environmental issue, which basically accounts the greenhouse gas (GHG) emissions and global warming potential. In contrast to that, it is required an analysis of any impact that both biomass and energy production may potentially cause. Based on that, studies have stressed the economic (McKINSKEY, 2009), environmental (LOARIE et al., 2011; MELLO et al., 2014) and social impacts (MARTINELLI et al., 2011; NOVO et al., 2012) of sugarcane to energy in Brazil.

Land availability, high level of investments and public incentives have led São Paulo state to become the national leader in bioenergy production. According to information from the São Paulo Energy Plan (PPE), about 50\% of the energy matrix in the state is composed of renewable energies, among them sugarcane biomass represents more than half of this parcel. Besides that, it is still expected that the state will continue to expand its bioenergy from sugarcane, mainly to the West region, replacing pastures and other agricultural areas (SÃO PAULO, 2012; EPE, 2013).

In the past decades, the increase of sugarcane areas in São Paulo has made the sector look for new boundaries in Brazil, as Central-West region. This region has been characterized by its land use changes at a large scale. As an example: deforestation of Cerrado biome, pasture intensification and monocultures taking place, such as soybean and sugarcane (BARRETTO et al., 2013; LAPOLA et al., 2013).

One of the causes of these land use dynamics over the country is due to the expansion of new sugarcane mills, motivated by the increasing demand for bioenergy, as well as the well known profitable sugar market. Therefore, big groups of sugarcane mills in São Paulo, through their branches, are looking for new areas to establish themselves, mainly in the states of Goiás, Minas Gerais, Mato Grosso do Sul and Mato Grosso (WALTER et al., 2011).

\section{The sugarcane straw in agricultural stage:}

Along with the modernization and the increase of bioenergy production, socio-environmental policies were established by the public sector in a way to improve not only the working conditions, but at the same time, to induce the modernization of the agriculture stage. In this sense, the main action taken in the state of São Paulo was the State Law number 11,242 from September of 2002, which establishes the gradual elimination of sugarcane burning harvest (ALESP, 2002). According to the Law, the ultimate goal proposes the elimination of $100 \%$ of the burn sugarcane in mechanized harvesting areas (up to $12 \%$ declivity) in São Paulo until 2021, and for non-mechanized areas (above 12\% declivity) the deadline is extended up to 2031. However, in 2007, the Agro Environmental Protocol, signed by UNICA (Union of Sugarcane Industry) and the Environmental Secretariat of São Paulo state, aimed to reduce these deadlines to 2014 (mechanized areas) and 2017 (non-mechanized areas). As a result of these policies, the reduction of burning harvest systems has increased, motivating some mills to seek for certifications to attend international production quality standards. Currently, the main sugarcane mill groups are already fulfilling sustainable categories and social responsibility (SÃO PAULO, 2014; BSI, 2014).

The sugarcane plant is essentially composed by three elements: stalk, green leaves and straw (dry leaves). Stalks are harvested and milled when sugars' concentration reaches optimal values for ethanol and sugar production. The amount of green leaves and straw varies throughout the crop cycle: in the beginning of the cycle, due to rainfall intensity and sun exposure, there are majority of green leaves. In the drier months, conversely, low temperatures and photosynthetic activity kick the senescence period off, when the green leaves undergo a continuous drying until the harvest day, and therefore, by the end of the cycle, the sugarcane plant basically composed by straw and stalk (RODRIGUES, 1995). 
Burning the straw is preferred in manual harvesting since it helps to separate stalks from straw and facilitate the manual chop, which has posed several socio-environmental issues, as previously pointed out. Regarding conventional mechanized harvest, the harvesters have an internal fan structure that sort out the stalk from the straw, which is thrown back to the field, known as "trash blanket" (BRAUNBECK et al., 1999; FORTES et al., 2012).

In regards of the eminent end of the manual harvest using burning system, several studies and incentives have undertaken efforts to the (re)use of sugarcane straw left on field for energy purposes (HASSUANI et al., 2005; LEAL et al. 2013). However, such studies are driven by several constraints regarding the sustainable use of this type of biomass, once it can affect directly the quality of the forthcoming sugarcane cycles. For this reason, assess the real availability of straw to be used by the mills for several purposes (especially for energy) compose a great share part of this specific agro-energy planning.

\section{Availability of s ugarca ne straw:}

Straw derived from different crops can be estimated, first and foremost, through several agricultural data sources in many scales (MILHAU \& FALLOT, 2013). According to SCARLAT et al. (2010), the crop residue production estimation, regardless the crop, must take into consideration five basic premises: production area, production yield, crop-straw ratio, residue removal rate concerning environmental constraints, soil conservation requirements and competitive uses (nonagricultural uses).

Referring to the sugarcane production area in Brazil, the studies have been increasingly requested this sort of data in both spatial aggregate and explicitly levels so as to attend the needs of the territorial planners. In aggregate manner, statistical data about production area for each agricultural year is available (at municipality level) at Brazilian Institute of Geography and Statistics (IBGE, 2013). Explicitly, developments in geotechnologies, with the use of satellite images has enabled greater precision in crop monitoring, area estimation, identification of harvesting methods and land use changes (AGUIAR et al., 2011; RUDORFF et al, 2010; ADAMI et al, 2012).

The sugarcane production yield, established by the amount of sugarcane produced (in tons) per unit of area (hectare) is highly heterogeneous, as it is influenced by several attributes such as climate, soil type, treatments, species, ratoon and many others (LANDELL \& BRESSIANI, 2010). In the Center South region, nonetheless, there is already a standardization regarding sugarcane yield, due to the similarity among the attributes that have major influence. Conversely, regarding the North and Northeast regions, the same does not happen and there are greater variations in yield values than Center South region, mainly due to different climate dynamics (MARTÍNEZ et al, 2013; IBGE, 2013).

From the production yield, it is possible to establish the straw to crop ratio, which is given by the ratio (i.e. percentage) of straw in the entire plant. SCARLAT et al. (2010) demonstrated through several literatures, that there is no universal model that can be applied for all crops. In fact, there are specific studies for each type of crop that consider several factors that influence in the crop residues production. In sugarcane case, HASSUANI et al. (2005) determine from an analysis of 10 different experiments that the avera ge of straw yield is 14.1 tons per hectare, yet in an analysis of three varieties and three sugarcane stages (plant, second ratoon and fourth ratoon), the average percentage of straw per sugarcane was $14 \%$. Besides the great variation among these numbers, LEAL et al. (2012) still added that sugarcane straw roughly consists in $62 \%$ of dry leaves, $31 \%$ of green leaves and $7 \%$ composed of superior parts; similarly, these values can vary a lot according to the variety of sugarcane and the period of the cycle.

Before direct the straw to its end-users (e.g. bioenergy plants), it is essential to consider the agronomic restriction, which play an important role throughout the sugarcane cycle. Among them, soil erosion is highlighted, once the straw maintenance over the field reduces environmental risks (FRANCO et al, 2013). Additionally, water deficits are minimized as the trash blanket on the 
ground decrease the soil evapotranspiration, just as increase the plant water content (ZINGARETTI et al., 2012). Moreover, this no till management improve the soil carbon stocks, which play a fundamental environmental role in tackling the soil carbon emissions, as reported by CERRI et al. (2011).

Other benefits such as micro fauna conservation, ecological restoration and local ecosystem alterations are also expected by leaving the straw on the field (DINARDO-MIRANDA \& FRACASSO, 2013; LAVELLE et al., 2006). However, the net amount of straw to be left on the soil are still uncertain as fields conditions differ in several aspects, like soil characteristics, climate, topography, management, among others (LEAL et al., 2012). For this reason, in the perspective of an "agro-energy action plan" using straw for large scale applications, it is important the adoption of approximated values to construct doable scenarios, as SEABRA \& MACEDO (2011), for example, suggesting that $40 \%$ of the straw available on the field could be used for energy purposes.

After the "agronomic stage," straw can be directed to several end users that are not necessarily for energy conversion. Although the current stage of the mills are still far from a biorefinery model, the production of high add value co-products like chemicals and biomaterials from sugarcane biomass has a great room for evolution (EICKHOUT, 2012; VAZ-JÚNIOR, 2011). Particularly for sugarcane straw, the studies have been mainly directed to short term feasible options, such as its use to supplement bagasse in bioelectricity production and second generation fuels (DIAS et al. 2011).

\section{Production chain of sugarcane straw to electricity:}

Agricultural residues in general and especially the straw have a great potential for energy production and have been evaluated in many studies at several scales (KIM \& DALE, 2004; BIDART et al., 2014). In Brazil, researches regarding sugarcane field residue reuse became evident in the 1990s in the former Copersucar Technological Center, where experimental tests on sugarcane harvest without burning were conducted, with straw available on the fields. Several benefits were observed after covering soil with straw, of which HASSUANI et al. (2005) highlighted: soil protection from water and wind erosion, reduction in soil thermal amplitude, increase of the biological activity in the soil and high water availability.

Considering these constraints in recovering the straw, it is important that the operation of straw recovery being strategically executed, once the mobilization of heavy machinery is required and this can result in agronomic losses such as soil compaction and the stepping of sugarcane sprouts (BELL et al., 2001). Therefore, careful evaluation of the agronomic environment is required; mainly in regards of the quantity of straw to be left in each area, once it supports decisionmaking on the amount of nutrients and additives required for a new sugarcane cycle (TRIVELIN et al., 2013). Besides this, the logistic planning of the mill-field-mill route, seeking to optimize the recovery process, enables to select which straw recovery route will be used for each sugarcane area. Currently, two routes of sugarcane straw recovery for energy purposes are normally highlighted in such studies (CARDOSO et al., 2013; CARDOSO, 2014): integral harvest and the bailing route.

As previously stressed, the main routes of straw recovery have been focused to energy conversion purposes such as cogeneration and second-generation ethanol production. The latter has been evidenced in major countries that have well established goals in reducing carbon emissions, such as USA mainly with corn stover (GRAHAM et al., 2007) and European Union (LEW ANDOWSKI et al., 2000). In Brazil, second-generation ethanol plants are still in the initial stages of use and in between 2013 and 2014, simulations and operations began at RAIZEN and GRANBIO. However, considering political issues and the advanced knowledge in Brazil of the first generation ethanol technology, it is believed that second generation ethanol will not be the predominant end use of sugarcane straw to fulfill the domestic demand in a short to medium term, (RAELE et al, 2014).

Similarly, cogeneration from agricultural residues has been set as a target in countries that energy matrix requires diversification towards less pollutant options. Consequently, several studies 
have aimed to analyze the techno-economic viability of future options, such as the combined cycles of biomass gasification (JIN et al., 2009) and the insertion of straw as a fuel in technological routes on a commercial scale (GRISI et al, 2011). Furthermore, external analysis on political and environmental factors seeks to boost the biomass to electricity as an important alternative to diversify energy matrix in many countries (JÄGER-WALDAU et al., 2011).

The cogeneration from sugarcane biomass, instead of second generation ethanol, has constantly grown in the past years and currently takes a relevant position in the Brazilian energy matrix and mainly in São Paulo state (EPE, 2013; SÃO PAULO, 2012). The majority of mills are currently using bagasse to cogenerate their own electricity required in the industrial plants, and in many cases, they are able to sell their surpluses to the grid. For this reason, the addition of straw as supplementary feedstock to bagasse composes an exclusively commercial activity in the mill, earning important revenues throughout cropping season.

However, in order to create a specific action plan for sugarcane straw to electricity, an intense agro-energy planning is required as this bioenergy system directly affect important drivers throughout the sugarcane to energy supply chain. This planning process would comprise the agricultural stage, with acquisition of new inputs for straw recovery; the industrial stage, with the retroffiting of the equipments (e.g. boilers); and also the transmission stage, with acquisition of new transmission lines to distribute the electricity cogenerated to the grid. Moreover, establish projections of supply and demand to support the decisions makers in the politic domain to propose subsidies for this bioenergy model.

\section{Geotechnologies in agro-energy planning:}

According to PRASAD et al., (2014) energy planning as whole can be defined as a script to recognize the energy requirements of a certain location. This type of planning is driven by several factors, like technology, economy, environment and social conjuncture; such factors that have direct impact on energy issues. However, for any type of planning that is aimed, it is important to have knowledge of the scale to work on, once this factor will be crucial in the effectiveness of a local application or in providing strategies to formulate public policies at regional/national levels (MIURA et al., 2011)

Geographical Information Systems (GIS), in this perspective, aiming to integrate the involved parts in the bioenergy framework so as to generate maps, recover, store and manipulate spatialized data, develop knowledge about the context and analyze all kinds of data (NOON \& DALY, 1996; SÁNCHEZ-LOZANO et al, 2013). Several studies have been conducted in the agro-energy planning scope using GIS in many information scales. VOIVONTAS et al. (2001) evaluated the production potential of electricity from agricultural residues integrating spatial and economic data in the Crete Island, pointing out that this type of system is capable to generate results for decision making in the energy scope and presents high flexibility regarding application in several locations. Concerning sugarcane to agro-energy planning, there is a lack of studies using this sort of platform but they demonstrate a great potential for application, as FRANCO (2008) evaluated in the study of potential areas for bioenergy expansion in the state of São Paulo.

Another important spatial data for agro-energy planning, mainly when biomass is used as a feedstock, is the remote sensing images (AHAMED et al., 2011). Its main advantages are represented by the data derived from spectral signatures of vegetation and possibilities to combine meteorological data for crop monitoring (EERENS et al., 2014). Currently, a large range of studies involving remote sensing with energy purposes has been conducted with sugarcane, gathering qualitative aspects, referring to biophysical parameters of the plant (SERRANO et al., 2002), and quantitative aspects mainly related to production estimation (PICOLI et al., 2009).

\section{Potential application of a spatial study on straw to electricity production chain:}

Seeking to provide a study that applies an evaluation of the straw to electricity production chain in a spatial manner, regardless of scale, it is important to separate the study in two modules of analysis. Firstly, developing the technical assessment of the potential straw to electricity, directly 
related to the straw availability. Subsequently, spatially assess the potential costs, aiming to guarantee an analysis that explores the feasibility of this bioenergy system. Also, it should be disclaim that the described model does not represent any specific case study; all the values regarding the straw potential to be explored and the costs involved in production chain were not included in this paper.

Referring to the investigation of straw potential available for cogeneration, the use of information derived from remote sensing can assure different levels of straw prospection according to the scale. Specifically to the use of images for agriculture residue prospection, a great part of these studies employ remote sensing for a direct evaluation, using the straw left on field as a target. This type of survey is characterized by local applications, due to spatial discontinuity of these residues along the cropping season, which may be a shortcoming regarding an evaluation of biomass potential. Nonetheless, the usage of sensors at a fine-scale enable greater precision in processed data (e.g. hyperspectral) and with high spatial resolution data, as demonstrated by BANNARI et al. (2006), which achieved worthy results in the identification of agricultural residues. On the other hand, there are also researches looking for potential assessments regardless of data precision, which is an indirect evaluation of residues whereby crop performance is investigated to estimate the quantity of residues. Under this approach, it is possible to work in less detailed scales, covering large areas like ELMORE et al. (2008) demonstrated with the spatial distribution of rice straw in China using satellite data of high temporal frequency and coarser spatial resolution.

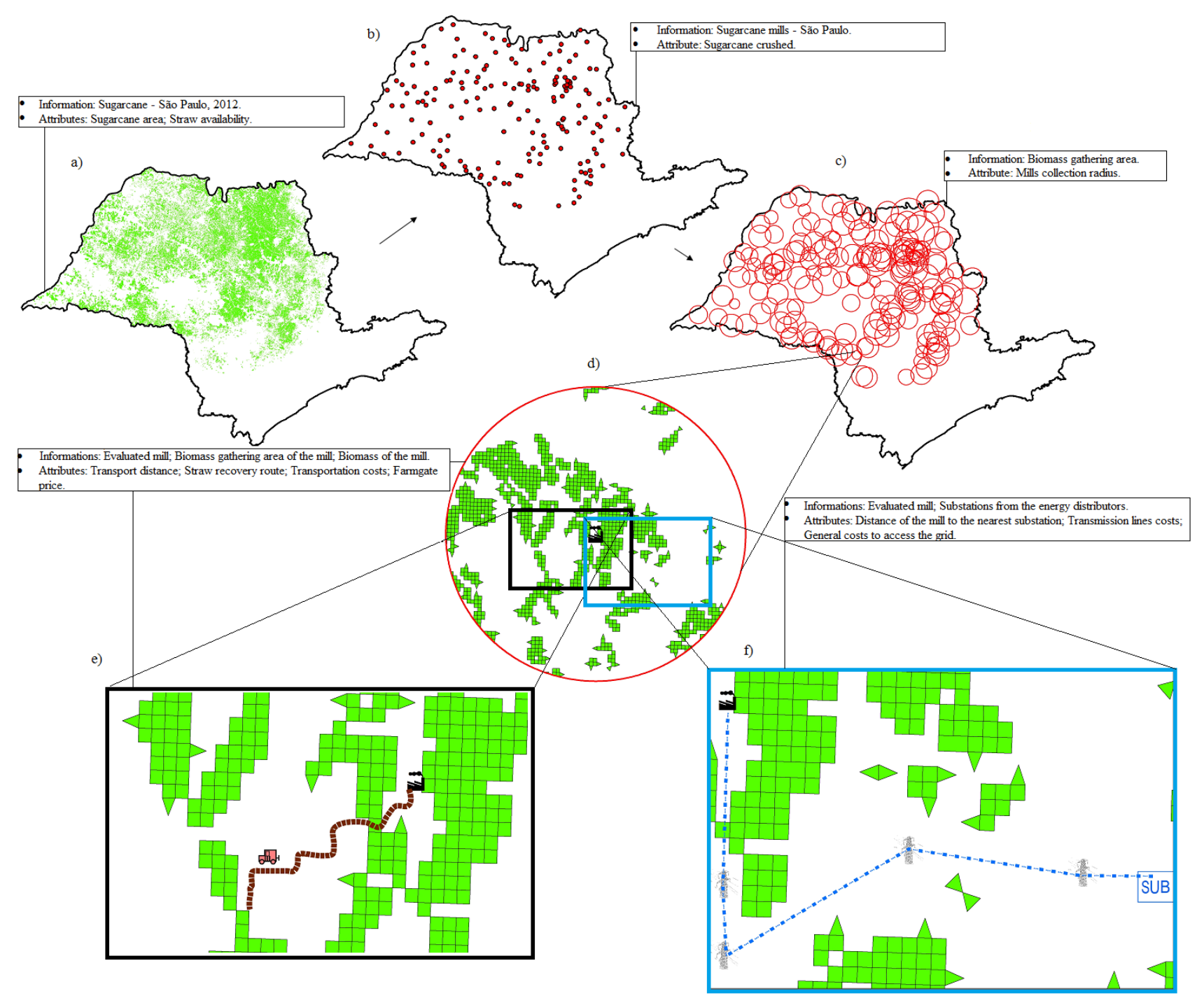

FIGURE 1. Conceptual spatial model to assess straw to electricity production chain. 
Considering the state of São Paulo as research area for the evaluation of the potentialities of bioelectricity generation from sugarcane straw, covering all the mills of São Paulo state, it is required to develop an indirect approach for straw prospection, using a spatial mask of sugarcane as a bas is (figure 1a) (RUDORFF et al., 2010). From the area information of this data, any information referring to straw availability can be associated, like the ones discussed in the availability of sugarcane straw section (e.g. sugarcane to straw ratio, straw removal rate). Yet, it should be pointed out that, associated with the information of sugarcane spatial mask data, geographic parameters like topography, climate, soils, among others, can also be inserted to generate information of the susceptibility to recover the straw in a certain location.

In an attempt to evaluate the potential straw to electricity for each mill in the state of São Paulo, it is required the estimation of their collection radius to define the biomass gathering area. For this purpose, spatial information of existing mills are used - figure 1b - (CTBE, 2014), associating the milling data to them (i.e. sugarcane crushed - information considered consistent to measure the size of a sugarcane mill) available at Sugarcane Yearbook (PROCANA, 2013).

Once milling information of each mill was obtained, it is necessary to identify which mill has the greatest milling number and relate this information to its collection radius. Information about collection radius can be acquired in contact with the mill, or through studies involving area of influence of biomass thermoelectric plants, that usually present an average radius nearly to $50 \mathrm{~km}$ (EDWARDS et al, 2005). Therefore, when relating the milling information with the collection radius of the largest mill, it is possible to stratify the collection radius for all subsequent mils to find their gathering areas, as demonstrated in figure 1c and detailed by CERVI (2015).

Especially for the state of São Paulo, as observed in figure 1c, due to the large number of mills, some with large gathering areas, several overlaps were detected, which hampers the separation and the extraction of biomass areas of each mill. Nevertheless, considering studies on biomass potential, these overlaps can be minimized using information about yield and selection of areas under great competition, as investigated by CERVI (2015). Thus, it is possible to assume the straw potential for cogeneration at mill scale, which concludes the first evaluation module of straw to electricity production chain.

The second module consist in an individual analysis of each mill (influence area - figure 1d), in the economic context to analyze viability to implement a cogeneration system that works with straw. In order to conduct this analysis in spatial mode, it is necessary to investigate the costs regarding the distances required to recover the straw for cogeneration and for transmission of the electricity produced.

Concerning straw recovery costs, the comprehension about evolution of straw supply costs according to the distance of mill-field-mill route is required. Several studies have evaluated the profitability to recover straw, mainly using integral harvest and bailing system (CARDOSO, 2014). Such researches are very complex once involves high agronomic/operational variability that each area/mill presents. Therefore, in order to develop this type of study for a spatial application, it is necessary to previously conduct an approach similar to the one that MICHELAZZO (2005) carried out, when analyzed the rising of straw recovery costs related to the distance, thereby establishing the logistic cost of straw recovery. Moreover, taking into consideration the capital and operational costs, it is necessary to establish the recovery cost that is embedded in each route of straw recovery, described in some studies of biomass logistics as farmgate price, which means the cost that the plant have to pay for the biomass supplier, regardless of the logistic cost (GRAHAM et a1., 1997). It is also worth to note that information about secondary roads or non-paved roads is scarce, for this reason, it is essential to incorporate a non-linearity factor in the distance between the area of collection and the mill (MONFORTI et al., 2013).

The costs of transmission, or to connect to the grid, depends not only on the mills $(60 \%$ of costs), but also on the distributors of the transmitted energy, which is responsible for about $40 \%$ of costs in the Brazilian case. Assuming that all the mills in the state of São Paulo need to invest in transmission lines to release its electricity produced, it is possible through the spatial data of the 
distribution substations, to measure the distance from the mill to the closest substations, and to consequently calculate the amount of investments required in transmission lines. Furthermore, as well as the investments in transmission lines, the mills should invest in their own substations, aiming to meet requirements of transmitted power voltage (CAVALCANTE, 2011). Bearing in mind the environmental implications regarding installation of transmission lines, the distance between the mill and collecting substation cannot be straight/direct due to geographic constraints, therefore, a factor of nonlinearity for the calculation, as well as in the distances of straw recovery, should also be used at a regional level.

\section{FINAL CONSIDERATIONS}

The contribution of spatial analysis to the agro-energy planning, as presented in the previous topic, can directly support the development of bioenergy systems on both a local and regional level. The use of sugarcane straw to electricity as a case study enable the incorporation of elements that can enhance the importance of spatial analysis to the agro-energy planning, such as biomass logistic, energy transmission and identification of consuming markets.

In Brazil, the agro-energy planning - particularly in the sugarcane sector - still has very few studies regarding the use of spatial analysis. The most highlighted ones usually present greater links to agricultural stage than to the whole production chain, such as estimations and forecasts of cropping season, in the evaluation of potential of land use and relate to direct or indirect land use changes.

Due to these findings, this study sought to highlight the importance of the spatial analysis throughout the sugarcane straw to electricity production chain - comprising the agricultural, operational and distribution stages. It is believed, however, that in order to achieve its full effectiveness, this conceptual model needs to be applied at regional level, highlighting the bioenergy technical and economical potential.

\section{REFERENCES}

ADAMI, M.; RUDORFF, B. F. T.; FREITAS, R. M.; AGUIAR, D. A.; AGUIAR, D. A.; SUGAWARA, L. M.; MELLO, M. P. Remote sensing time series to evaluate direct land use change of recent expanded sugarcane crop in Brazil. Sustainability, Cambridge, v. 4, p. 574-585, 2012.

AGUIAR, D.A.; RUDORFF, B.F.T.; SILVA, W.F.; ADAMI, M.; MELLO, M.P. Remote sensing images in support of environmental protocol: monitoring the sugarcane harvest in São Paulo State, Brazil. Remote Sensing, Basel, v.3, n.12, p.2682-2703, 2011.

AHAMED, T.; TIAN, L.; ZHANG, Y.; TING, K. C. A review of remote sensing methods for biomass feedstock production. Biomass and Bioenergy, Oxford, v.35, n.7, p.2455-2469, 2011.

ALESP - Assembleia Legis lativa do Estado de São Paulo. Texto da Lei n. 11.241, de 19 de setembro de 2002. São Paulo, 2002. Disponível em:

<http://www.al.sp.gov.br/legis lacao/norma.do?id=217>. Acesso em: mar. 2014.

AMORIM, G. Biocombustíveis e investimento externo. Análise Conjuntural, Curitiba, v.29, n.5-6, p.8-10, maio/jun., 2007.

ANEEL - Agencia Nacional de Energia Elétrica. Banco de informações de geração. Disponível em: <http://www.aneel.gov.br/area.cfm?idArea=15>. Acesso em: maio 2013.

BANNARI; A., PACHECO, A.; STAENZ, K..; MCNAIRN, H.; OMARI, K. Estimating and mapping crop residues cover on agricultural lands using hyperspectral and IKONOS data. Remote Sensing of Environment, New York, v.104, n.4, p.447-459, 2006.

BARRETTO, ALBERTO G. O. P.; BERNDES, GÖRAN; SPAROVEK, G.; WIRSENIUS S. Agricultural intensification in Brazil and its effects on land-use patterns: an analysis of the 19752006 period. Global Change Biology, Oxford, v.19, n.6, p.1804-1815, 2013. 
BELL, M.J.; HALPIN, N.V.; ORANGE, D.N.; HAINES, M. Effect of compaction and trash blanketing on rainfall infiltration in sugarcane soils. Proceedings of the 2001 Conference of the Australian Society of Sugar Cane Technologists, Queensland, 2001, p.161-167.

BIDART, C.; FRÖHLING, M.; SCHULTMANN, F. Livestock manure and crop residue for energy generation: Macro-assessment at a national scale. Rene wable and Sustainable Energy Reviews, Amsterdam, v.38, p.537-550, out. 2014.

BRAUNBECK, O. A.; CORTEZ, L. A. B.; ROSILLO-CALLE, F.; BAUEN, A. Prospects for Green Cane Harvesting and Cane Residue Use in Brazil. Biomass \& Bioenergy, Oxford, v.17, n.1, p.495-506, 1999.

BSI - Better Sugarcane Initiative. Padrão de produção. 2014. Disponivel em:

<http://www.bonsucro.com/>. Acesso em: mar. 2014.

BUCKERIDGE, M. S.; SOUZA, A. P.; ARUNDALE, R. A.; ANDERSON-TEIXEIRA, K. J.; DELUCIA, E. Ethanol from sugarcane in Brazil: a midway strategy for increasing ethanol production while maximizing environmental benefits. GCB BIOENERGY, Oxford, v.4, n.2, p.119-126, 2012.

CANASAT. Monitoramento da cana de açúcar. Disponível em:

<http://www.dsr.inpe.br/laf/canasat/colheita.html>. Acesso em: out. 2013.

CARDOSO, T. F.; CAVALETT, O.; CHAGAS, M. F.; MORAIS, E. R.; CARVALHO, J. L. N.; FRANCO, H. C. J.; GALDOS, M. V.; SCARPARE, F. V.; BRAUNBECK, O. A.; CORTEZ, L. A. B.; BONOMI, A. Technical and economic assessment of trash recovery in the sugarcane bioenergy production system. Scientia Agrícola (USP. Impresso), v. 70, p. 353-360, 2013.

CARDOSO, T. F. Avaliação socioeconômica e ambiental de sistemas de recolhimento e uso da palha de cana de açúcar. $176 \mathrm{f}$. Tese (Doutorado em Engenharia Agrícola) - Faculdade de Engenharia Agrícola, Universidade Estadual de Campinas, Campinas. 2014.

CAVALCANTE, J. A. Subsídios para o planejamento da utilização do potencial de excedentes de energia elétrica de cogeração no setor sucroalcooleiro. 2011. 218 f. (Dis sertação de Mestrado) - Faculdade de Engenharia Mecânica, Universidade Estadual de Campinas, Campinas. 2011.

CERRI, C. C.; GALDOS, M. V.; MAIA, S. M. F.; BERNOUX, M.; FEIGL, B. J.; POWLSON, D.; CERRI, C. E. P. Effect of sugarcane harvesting systems on soil carbon stocks in Brazil: an examination of existing data. European Journal of Soil Science, Oxford, v.62, n.1, p.23-28, 2011.

CERVI, W.R. Spatial approach of costs and the potential straw to energy in São Paulo state. Thesis. Campinas, SP, 2015.

CTBE - Centro de Tecnologia do Bioetanol. Mapa das usinas de açúcar e álcool do B rasil. Campinas. 2013. Disponível em: <http://ctbe.cnpem.br/pesquisa/producao-biomas sa/cana-info/> Acesso em: nov. 2014

DIAS, M.O.S.; CUNHA, M. P.; JESUS, C.D.F.; ROCHA, G.J.M.; PRADELLA, J. G. C.; ROSSELL, C. E.V.; MACIEL FILHO, R.; BONOMI, A. Second generation ethanol in Brazil: Can it compete with electricity production? Bioresource Technology, New York, v.102, n.19, p.8964-8971, 2011.

DINARDO-MIRANDA, L. L.; FRACASSO, J. V. Sugarcane straw and the populations of pestsand nematodes. Scientia Agricola, Piracicaba, v.70, n.5, p.305-310, 2013.

EDWARDS, R.A.H., ŠÚRI, M., HULD, T., DALLEMAND, J.F., 2005. GIS-based assessment of cereal straw energy resource in the EU. In: EUROPEAN BIOMASS CONFERENCE AND EXHIBITION. BIOMASS FOR ENERGY, INDUSTRY AND CLIMATE PROTECTION, 14., 2005, Paris. Anais... p.17-21.

EERENS, H.; HAESEN, D.; REMBOLD, F.; URBANO, F.; TOTE, C.; BYDEKERKE, L. Image time series processing for agriculture monitoring. Environmental Modelling and

Software, Oxford, v.53, p.154-162, 2014. 
EICKHOUT, B. A strategy for a bio-based economy. Belgium: Green European Foundation; 2012. Disponívelem: 〈http://gef.eu/uploads/media/A_strategy_for_a_bio-based_economy.pdf>. Acesso em: jul. 2014.

ELMORE, A. J., SHI, X., GORENCE, N. J., LI, X., JIN, H., WANG, F., AND ZHANG, X. Spatial distribution of agricultural residue from rice for potential biofuel production in China. Biomass and Bioenergy, Oxford, v.32, n.1, p.22-27, 2008.

EPE - Empresa de Pesquisa Energética. Plano decenal de expansão de energia 2022. Brasília, DF: Ministério de Minas e Energia, 2013.

FAPESP - Fundação de Amparo à Pesquisa do Estado de São Paulo. Relatório de Atividades 2012. Disponível em: <http://www.fapesp.br/publicacoes/relat2012_completo.pdf >. Acesso em: dez. 2013

FRANCO, M. M. Aplicação de técnicas de análise espacial para a avaliação do potencial de produção de eletricidade a partir de subprodutos da cana de açúcar no estado de São Paulo. 2008. 120f. Dissertação (Mestrado) - Faculdade de Engenharia Mecânica, Planejamento de Sistemas Energéticos, Universidade Estadual de Campinas, Campinas, 2008.

FRANCO, H.C.J.; PIMENTA, M. T. B.; CARVALHO, J. L. N.; MAGALHAES, P. S. G.; ROSSELL, C. E. V.; BRAUNBECK, O. A.; VITTI, A.C.; KOLLN, O. T.; ROSSI NETO, J. Assessment of sugarcane trash for agronomic and energy purposes in Brazil. Scientia Agrícola Piracicaba, v.70, n.5, p.305-312, 2013.

FREITAS, L. C. de; KANEKO, S. Ethanol demand in Brazil: Regional approach. Energy Policy, v.39, n.5, p.2289-2298, 2011.

FORTES, C.; TRIVELIN, P. C. O.; VITTI, A. C. Long-term decomposition of sugarcane harvest residues in Sao Paulo state, Brazil. Biomass \& Bioenergy, Oxford, v.42, p.189-198, 2012.

GRAHAM, R. L., LIU, W., DOWNING, M., NOON, C. E., DALY, M., MOORE, A. The effect of location and facility demand on the marginal cost of delivered wood chips from energy crops: A case study of the state of Tennessee. B iomass \& Bioenergy, Oxford, v.13, p.117-123, 1997.

GRAHAM, R. L.; NELSON R.; SHEEHAN, J.; PERLACK, R. D.; WRIGHT, L. L. Current and potential US corn stover supplies. Agronomy Journal, Madison, v.99, n.1, p.1-11, 2007.

GRISI, E. F.; YUSTA, J. M.; KHODR, H. M. A short-term scheduling for the optimal operation of biorefineries. Ene rgy Conversion and Management, Oxford, v.52, n.1, p.447-456, 2011.

HASSUANI, S.J., LEAL, M.R.L.V., MACEDO, I.C. Biomass power generation: s ugar cane bagasse and trash. Piracicaba: PNUD-CTC, 2005, 217p. (Serie Caminhos para Sustentabilidade).

IBGE - Instituto Brasileiro de Geografia e Estatística. Produção Agrícola Municipal. Brasília, DF, 2013.

IPCC - Intergovernmental Panel on C limate Change. IPCC mitigation of climate change. 1996. Disponível em: <http://www.ipcc.ch/report/ar5/wg3/>. Acesso em: nov. 2014.

JÄGER-WALDAU, A.; SZABÓ, M.; SCARLAT, N.; MONFORTI-FERRARIO, F. Renewable electricity in Europe. Renewable and Sustainable Energy Reviews, Amsterdam, v.15, n.8, p.3703-3716, 2011.

JIN, H.; LARSON, E. D.; CELIK, F. E. Performance and cost analysis of future, commercially mature gasification-based electric power generation from switchgrass. Biofuels, Biorproducts \& Biorefining, Chichester, v.3, p.142-173, 2009.

KIM, S.; DALE, B. E. Global potential bioethanol production from wasted crops and crop residues. Biomass and Bioenergy, Oxford, v.26, n.4, p.361-375, 2004. 
LAMERS, P.; HAMELINCK, C.; JUNGINGER, M.; FAAIJ, A. International bioenergy trade - A review of past developments in the liquid biofuel market. Renewable and Sustainable Energy Reviews, Amsterdam, v.15, n.6, p.2655-2676, 2011.

LANDELL, M. G. A.; BRESSIANI, J. A. Melhoramento genético e manejo varietal. In: DINARDO-MIRANDA, L. L.; VASCONCELOS, A.C.M.; LANDELL, M. G. A. (Org.). Cana-deAçúcar. Campinas: Instituto Agronômico de Campinas, 2010. v. 1, p. 101-156.

LAPOLA, D. M.; MARTINELLI, L. A.; PERES, C. A.; OMETTO, J. P. H. B.; FERREIRA, M. E.; NOBRE, C.; AGUIAR, A. P. D.; BUSTAMANTE, M. M. C.; CARDOSO, M. F.; COSTA, M. H.; JOLY, C. A.; LEITE, C. C.; MOUTINHO, P.; SAMPAIO, G.; STRASSBURG, B. B. N.; VIEIRA, I. C. G. Pervasive transition of the Brazilian land-use system. Nature Climate Change, London, v.4, p.27-35, 2013.

LAVELLE P.; DECAENS T.; AAUBERT M.; BAROT S.; BLOUIN M.; BUREAU F.; MARGERIE P.; MORA P.; ROSSI, J. P. Soil invertebrates and ecosystem services. European Journal of Soil Biology, Paris, v.42, p.S3-S15, 2006.

LEAL, M.R.L.V.; GALDOS, M.V.; SCARPARE, F.V.; SEABRA, J.E.A.; WALTER, A.; OLIVEIRA, C.O.F. Important issues related to sugarcane straw availability, quality and use. In: EUROPEAN BIOMASS CONFERENCE, 20., 2012, Milan. Proceedings...

LEAL, M. R. L. V ; GALDOS, M. V.; SCARPARE, F. V.; SEABRA, J. E.; WALTER, A.; OLIVEIRA, C. O. F. Sugarcane straw availability, quality, recovery and energy use: A literature review. Biomass and Bioene rgy, Oxford, v.53, p.11-19, jun. 2013.

LEAL, M. R. L. V.; MACEDO, I.C. Evolução tecnológica dos sistemas de geração de energia nas usinas de açúcar e álcool. Biomassa e Energia, Dourados, v.1, n.3, p.245-253, 2004.

LEWANDOWSKI, I.; CLIFTON-BROWN, J. C.; SCURLOCK, J. M. O.; HUISMAN, W. Miscanthus: European experience with a novel energy crop. Biomass and Bioenergy, Oxford, v.19, p.209-227, 2000.

LOARIE, S.R.; LOBELL, D.B.; ASNER, G.P.; MU, Q.; FIELD, C.B. Direct impacts on local climate of sugar-cane expansion in Brazil. Nature Climate Change, London, v.1, n.2, p.105-109, 2011.

MARTINELLI, L. A.; GARRETT, R.; FERRAZ, S.; NAYLOR, R. Sugar and ethanol production as a rural development strategy in Brazil: Evidence from the state of Sao Paulo. Agricultural Systems, England, v. 104, n.5, p.419-428, 2011.

MARTÍNEZ, S. H.; VAN EIJCK, J.; PEREIRA DA CUNHA, M.; GUILHOTO, J. J. M.; WALTER, A.; FAAIJ, A. Analysis of socio-economic impacts of sustainable sugarcane-ethanol production by means of inter-regional input-output analys is: Demonstrated for Northeast Brazil.

Renewable and Sustainable Energy Reviews, Amsterdam, v.28, p.290-316, 2013.

McKINSKEY. Pathways to a low carbon economy - Version 2 of the global GHG abatement costs curve. New York: McKinkey \& company, 2009

MELLO, F. F. C.; CERRI, C. E. P.; DAVIES, C.; HOLBROOK, N. M.; PAUSTIAN, K.; MAIA, S. M. F.; GALDOS, M. V.; BERNOUX, M.; CERRI, C.C. Paybacktime for soil carbon and sugarcane ethanol. Nature Climate Change, London, v.4, p.605-609, 2014.

MICHELAZZO, M. B. Análise de sensibilidade de seis sistemas de recolhimento do palhiço da cana-de-açúcar (Saccharum spp.). 2005. 86f. (Mestrado em Engenharia Agrícola) - Faculdade de Engenharia Agrícola, Universidade Estadual de Campinas, Campinas, 2005.

MILHAU A., FALLOT, A. Assessing the potentials of agricultural residues for energy: What the CDM experience of India tells us about their availability. Ene rgy Policy, v.58, p.391-402, 2013. 
MIURA, A. K.; FORMAGGIO, A. R.; SHIMABUK URO, Y. E.; LUIZ, ALFREDO, J. B.; SILVA, S. D. A. E. Avaliação de áreas potenciais ao cultivo de biomassa para produção de energia e uma contribuição de sensoriamento remoto e sistemas de informações geográficas. Engenharia Agrícola, Jaboticabal, v.31, n.3, p.607-620, 2011.

MONFORTI, F.; BODIS, K.; SCARLAT, N.; DALLEMAND, J. F. The possible contribution of agricultural crop residues to renewable energy targets in Europe: A spatially explicit study.

Renewable and Sustainable Energy Reviews, Amsterdam, v.19, p.666-677, 2013.

NOON, C. E.; DALY, M. J. GIS-based biomass resource assessment with BRAVO. Biomass and Bioenergy, Oxfod, v.10, n.2-3, p.101-109, 1996.

NOVO, A.; JANSEN, K.; SLINGERLAND, M. The sugarcane-biofuel expansion and dairy farmers' responses in Brazil. Journal of Rural Studies, Oxford, v.28, n.4, p.640-649, 2012.

PICOLI, M. C. A.; RUDORFF, B. F. T.; RIZZI, R.; GIAROLLA, A. Índice de vegetação do sensor MODIS na estimativa da produtividade agrícola da cana-de-açúcar. B ragantia, Campinas, v.68, p.789-795, 2009.

PRASAD, R. D.; BANSAL, R. C.; RATURI, A. Multi-faceted energy planning: A review.

Renewable and Sustainable Energy Reviews, Amsterdam, v.38, p.686-699, 2014.

PROCANA. Centro de Informações Sucroenergéticas. Anuário da cana 2013 - B razilian sugar and ethanol guide. Ribeirão Preto, 2013.

RAELE, R..; BOAVENTURA, J. M. G.; FISCHMANN, A. A.; SARTURI, G. Scenarios for the second generation ethanol in Brazil. Technological Forecasting and Social Change, New York, v.87, p.205-223, 2014.

RODRIGUES, J. D. Fisiologia da cana-de-açúcar. Botucatu: Instituto de Biociências Universidade Estadual Paulista, 1995. 101p. Apostila. Disponível em:

<http://pt.slideshare.net/catetoferrazl/fisiologia-da-cana-deaucar>. Acesso: em set. 2014.

RUDORFF, B. F. T.; AGUIAR, D. A.; SILVA, W. F.; SUGAWARA, L. M.; ADAMI, M.;

MOREIRA, M. A. Studies on the rapid expansion of sugarcane for ethanol production in São Paulo state (Brazil) using Landsat data. Remote Sensing, New York, v.2, n.4, p.1057-1076, 2010.

SÁNCHEZ-LOZANO, J. M.; TERUEL-SOLANO, J.; SOTO-ELVIRA, P. L.; GARCÍA-

CASCALES, M. S. Geographical Information Systems (GIS) and Multi-Criteria Decision Making

(MCDM) methods for the evaluation of solar farms locations: Case study in south-eastern Spain.

Renewable and Sustainable Energy Reviews, Amsterdam, v.24, p.544-556, 2013.

SÃO PAULO (Estado). Secretaria de Energia. Balanço Energético do estado de São Paulo - 2013 Ano Base/2012. Disponível em:

<http://www.energia.sp.gov.br/a2sitebox/arquivos/documentos/541.pdf>. Acesso em: set. 2014.

SÃO PAULO (Estado). Secretaria do Meio Ambiente. Protocolo agroambiental do setor sucroene rgético paulista: dados consolidados das safras 2007/2008 a 2013/2014. Disponível em: $<$ http://www.ambiente.sp.go v.br/etanolverde/files/2014/12/Protocolo-Agroambiental-do-SetorSucroenerg\%C3\% A9tico-Relat\%C3\%B3rio-consolidado.pdf >. Acesso em: dez. 2014.

SCARLAT, N.; MARTINOV, M.; DALLEMAND, J. F. Assessment of the availability of agricultural crop residues in the European Union: potential and limitations for bioenergy use. Waste Management, Oxford, v.30, n.10, p.1889-1897, 2010.

SEABRA, J. E. A.; MACEDO, I. C. Comparative analysis for power generation and ethanol production from sugarcane residual biomass in Brazil. Energy Policy, v.39, n.1, p.421-428, 2011.

SERRANO, L.; PEÑUELAS, J.; USTIN, S. L. Remote sensing of nitrogen and lignin in Mediterranean vegetation from AVIRIS data: Decomposing biochemical from structural signals.

Remote Sensing of Environment, New York, v.81, n.2-3, p.355-364, 2002. 
THOMAS, A.; BOND, A.; HISCOCK, K. A GIS based assessment of bioenergy potential in England within existing energy systems. Biomass and Bioenergy, Oxford, v.55, p.107-121, 2013.

TRIVELIN, P.C.O.; FRANCO, H. C. J.; OTTO, R.; FERREIRA, D. A.; VITTI, A. C.; FORTES, C.; FARONI, C. E.; OLIVEIRA, E. C. A.; CANTARELLA, H. Impact of sugarcane trash on fertilizer requirements for São Paulo, Brazil. Scientia Agricola, Piracicaba, v.70, n.5, p.345-352, 2013.

UNICA - União da Indústria de Cana-de-Açucar. Dados de Produção. Disponível em: <http://www.unicadata.com.br/>. Acesso em: out. 2013.

VAZ-JÚNIOR, S. (Org.). Biorrefinarias: cenários e perspectivas. Brasília, DF: Embrapa, 2011. v.1. $176 \mathrm{p}$.

VOIVONTAS, D.; ASSIMACOUPOULOS, D.; KOUKIOS, E. G. Assessment of biomass potential 407 for power production: a GIS based method. Biomass and Bioenergy, Oxford, v.20, n.2, p.101-112, 2001.

WALTER, A.; DOLZAN, P.; QUILODRAN, O. A.; SILVA, C.; PIACENTE, F. J.;

SEGERSTEDT, A. Sustainability as sessment of bio-ethanol production in Brazil considering land use change, GHG emissions and socio-economic aspects. Energy Policy, v.39, p.5703-5716, 2011.

ZINGARETTI, S.; RODRIGUES, F. A.; GRAÇA, J. P.; PEREIRA, L. M.; LOURENCO, M. V. Sugarcane responses at water deficit conditions. In: INTECH. Water Stress. Rijeka: Intech, 2012, p.255-276. 